\title{
W LUDZKIM I W NIE-LUDZKIM ŚWIECIE. (PO)NOWOCZESNE SPOŁECZEŃSTWO A PŁEĆ ŻEŃSKA W MRÓWKACH MARII PAWLIKOWSKIE]-JASNORZEWSKIE]
}

\section{ALEKSANDRA BANOT}

\section{IN THE HUMAN AND THE NON-HUMAN WORLD. (POST)MODERN SOCIETY AND THE FEMALE SEX IN MRÓWKI (ANTS) BY MARIA PAWLIKOWSKA- JASNORZEWSKA}

ABSTRACT Mrówki. Sztuka $w$ trzech aktach (Ants. A Play in Three Acts) by Maria Pawlikowska-Jasnorzewska (premiered in 1936) juxtaposes two worlds: the animal world, the community of ants, and the human world, the family as a social unit. In both worlds dramas play out with female individuals at their centre, who are in love and who refuse to perceive love as nothing more than a tool subjugated to biological reproduction.

In the present article I will be mostly interested in following and attempting to reconstruct such quasi-oppositions as: ants - humans, society - individual, female-male, sexual act - love, reproduction - production, life - death, zoe - bios. I will also set out to consider how Ants are situated in relation to literary traditions of therianthropy and animal fables - is the image of the anthill embedded in an anthropocentric perspective or whether it may be inscribed in the posthumanist discourse. Finally, I will look at the "anthill civilisation" - the society of the early $20^{\text {th }}$ century, struggling with urbanisation, industrialisation, technicisation, but also developing totalitarian tendencies. This problem, though frequently taken up by critics and scholars, appears still to be current today.

KEY WORDS Maria Pawlikowska-Jasnorzewska, drama, society, female sex, (post)modernity, posthumanism

CONTACT Akademia Techniczno-Humanistyczna w Bielsku-Białej, abanot@ath.bielsko.pl 


\section{1 / WPROWADZENIE}

Jednym z nielicznych niekonwencjonalnych dramatów Marii Pawlikowskiej-Jasnorzewskiej są Mrówki. Ta powstała przed 1932 rokiem Sztuka w trzech aktach (jak głosi podtytuł) miała prapremierę w 1936 roku w krakowskim Teatrze im. Juliusza Słowackiego (Szałagan 1999: 287). Odniosła duży sukces sceniczny, o czym pisali recenzenci - Tadeusz Sinko nazwał premierę Mrówek „prawdziwym zdarzeniem teatralnym” (1936: 6), zaś Krystyna Grzybowska uznała ją za jedno „Z najważniejszych wydarzeń artystycznych obecnego sezonu teatralnego” (1936: 6). Kazimierz Wyka, jeden z najbardziej uzdolnionych krytyków literackich młodego pokolenia, zanotował z kolei: „[...] Mrówki mimo tych czy owych potknięć w zasadniczej strukturze sztuki stanowią [...] najśmielszy pomysł, na jaki zdobył się kiedykolwiek teatr polski, gdy pamiętać będziemy o tak rzadkim połączeniu swobody poetyckiej z niecierpliwością o losy jednostki" (Wyka 1936: 4).

Mrówki, „zwierzęco-ludzka paralela” (Treugutt 1986: 15), zestawiają dwa światy, dwa makro- a zarazem mikrokosmosy: świat zwierząt, społeczność mrówek i świat ludzi, rodzinę społeczną komórkę. W obydwu społecznościach rozgrywają się dramaty jednostek - zakochanych przedstawicielek rodzaju żeńskiego, które nie godzą się na rozumienie miłości jako narzędzia podporządkowanego wyłącznie biologicznej reprodukcji.

Paralelizm, który odsyła do poszukiwania podobieństw i różnic, nie wydaje się najważniejszą kategorią interpretacyjną dramatu Pawlikowskiej-Jasnorzewskiej. O wiele istotniejsze jest potraktowanie obydwu światów w kategoriach opozycji: mrówki - ludzie, społeczeństwo jednostka, żeńskie - męskie, akt seksualny - miłość, reprodukcja - produkcja, pragmatyczne - estetyczne, biologiczne - psychologiczne, życie - śmierć, zoe-bios. Łatwo zauważyć, że te pary nie mają jednoznacznie opozycyjnego charakteru, nie stanowią przeciwległych biegunów. Wymienionych pojęć nie sposób jasno zdefiniować. Ich semantyczne granice są nieostre. Co więcej - tworzą nie tyle jedno kontinuum w obszarze pary, ile raczej kontinua krzyżujące się czy splątane.

Nie można pominąć innego ważnego problemu dramatu Pawlikowskiej-Jasnorzewskiej, na który zwracali uwagę badacze, m.in. Maria Józefacka i Marian Rawiński - samego wyboru takiej paraleli. Zarówno bajkowa, jak i baśniowa konwencja, z której korzysta autorka Egipskiej pszenicy, a w której zwierzęta mają być alegorią ludzkich cech oraz nawyków, legitymuje się długą i różnorodną historią w literaturze i w kulturze starożytnej oraz nowożytnej. Obecność tej konwencji niesie za sobą konsekwencje - wymaga od badacza refleksji nad organizacją ludzkiego i nie-ludzkiego społeczeństwa.

Interesować mnie zatem będzie nie tylko prześledzenie wymienionych quasi-opozycji, próba ich rekonstrukcji. Spróbuję odpowiedzieć także na pytanie o to, jak Mrówki sytuują się wobec tradycji literackich teriantropii i bajek zwierzęcych: czy obraz mrowiska jest osadzony w perspektywie antropocentrycznej (por. Dąbrowska 2018:29); ${ }^{1}$ czy może wpisuje się w taki posthumanistyczny dyskurs, w którym „stawanie się zwierzęciem” zostaje włączone „[...] w kon-

1 Tekst dramatyczny, który jest przedmiotem moich badań, ogranicza rozważania do analizy owadów jako kulturowych konstruktów. Nie oznacza to jednak utraty z pola widzenia biologii mrówek jako konkretnych przedstawicielek królestwa zwierząt. Brak jasno postawionych granic pomiędzy tymi dwoma perspektywami warunkuje określone tezy badawcze i interpretacyjne tropy, czasem być może sprzeczne, częściej jednak komplementarne. Sygnalizując wskazany problem, nie będę starała się skrupulatnie wyznaczać owych granic - wydaje się to bardzo trudne, a często wręcz niemożliwe. 
cepcję wzbogacania człowieka pierwiastkiem nieuświadomionej dotąd, odkrywanej stopniowo zwierzęcości" (Kaszowska-Wandor 2018: 55). Innymi słowy: czy analizowany dramat z lat 30. $\mathrm{XX}$ wieku jest formą uczłowieczenia zwierząt, czy może uzwierzęcenia (animalizacji) ludzi. A może zarówno jednego, jak i drugiego? Warto jednocześnie pamiętać, że to nie posthumanizm przełomu XX i XXI wieku, ale raczej dziewiętnastowieczny ewolucjonizm darwinowski odkrył ludzkie zwierzę. Wskazanie różnic w obydwu dyskursach wymagałoby jednak odrębnego artykułu.

Przyjrzę się wreszcie „cywilizacji mrowiska” - społeczeństwa początku XX wieku zmagającego się z urbanizacją, industrializacją, technicyzacją, jak też z rozwojem tendencji totalitarnych. Ten problem, choć często podejmowany przez krytyków i badaczy, wydaje się ciągle aktualny.

\section{2 / W LUDZKIM I W NIE-LUDZKIM MROWISKU}

Mrówki są jedną z mniej znanych sztuk Pawlikowskiej-Jasnorzewskiej, dlatego warto przybliżyć tutaj ich fabułę. Pierwszy i trzeci akt dramatu rozgrywa się w mrowisku. Społeczność mrówek przygotowuje się do lotu godowego uskrzydlonych owadów. Kolejne sceny przedstawiają szeregowe robotnice pochłonięte pracą zarządzaną przez Xax, Xaurę i Xanto oraz skrzydlate księżniczki, które niecierpliwie oczekują miłosnego połączenia z przeznaczonymi dla nich książętami, nieświadome swego późniejszego losu - ciężarnych samic z obciętymi skrzydłami uwięzionych w jednej z komór mrowiska. Jedna z nich, Illi, jest przekonana o wyższości miłości rozumianej jako (prawdziwe) życie nad pracą-poświęceniem. Apeluje ona do robotnic: „Obudźcie się! Przepracujecie młodość, nie wiedząc, co to nadzieja i radość. Otrząśnijcie się!”. I dalej: „Nie poświęcajcie się! I wy macie prawo do życia!” (Pawlikowska-Jasnorzewska 1986: 351). ${ }^{2}$ Ponadto Illi dowodzi, że „[...] nie chodzi o społeczeństwo, ale o szczęście jednostki, dla którego mrowisko istnieje i tyle trudu sobie zadaje" (s. 347).

Akt trzeci rozpoczyna się rozmową Xax i Xanto o udanym locie godowym skrzydlatych samic i trutni oraz o ich dalszym losie - zapłodnione księżniczki zostaną matkami, zaś książęta zginą. Xanto mówi: „Prawom stało się zadość. Życie gatunku zapewnione. Truteń zrobił swoje, truteń może odejść. Tych darmozjadów trzymać i żywić byłoby nonsensem. A księżniczki potrafimy zmusić do zapłodnienia” (s. 408). Informują one Illi, „buntownicę i erotomankę” (s. 417), że jej kochanek Sydis zginął, podobnie jak inne trutnie, zaś ona sama zostanie pozbawiona skrzydeł („Mrowisko dało skrzydła - mrowisko wzięło!”, s. 423) i będzie rodzić dzieci. Illi bezskutecznie próbuje uciec z mrowiska. Kiedy jej skrzydła zostają obcięte, mówi: „Nie chcę rodzić nieszczęśliwych. Jako kochanka, jako okaleczona ofiara waszego systemu, protestuję! Jednostka to więcej niż mrowisko. Mrowisko jest złudzeniem" (s. 424). Finałowe sceny przedstawiają zniszczenie mrowiska spowodowane działalnością ludzkiego dziecka i śmierć wielu mrówek. Tę mrówczą apokalipsę przeżywa Illi, która porzuca indywidualizm na rzecz społecznego interesu i zapowiada odbudowę mrowiska: „[...] moje potomstwo odbuduje mrowisko! We mnie nadzieja i przyszłość! Towarzyszki, do mnie. Część poległym! Pracuj!” (s. 428)

Drugi akt Mrówek rozgrywa się „wśród ludzi” (s. 371). Do jednej z bohaterek, Eugenii, nazywanej Giną, przychodzi w odwiedziny przyjaciółka, Mira. Rozmawiają o wyjeździe Giny 
i jej męża Kajetana, przyrodnika, do Afryki. Gina wyjawia przyjaciółce sekret - niedawno potwierdziły się jej podejrzenia, że jest w ciąży. Postanowiła jednak dokonać aborcji i pojechać razem z mężem do Afryki, opóźniając wyjazd o tydzień. Mira jest przekonana, że Gina nie ma prawa decydować o przerwaniu ciąży. Telefonuje ona do doktora przyjaciółki, ostrzegając go, $\dot{z ̇ e}$ „rodzina sobie nie życzy żadnej lekarskiej interwencji [...]” (s. 378). Mira ponadto informuje o ciąży matkę Giny, panią Xawerę, która jest oburzona tym, że córka „chce popełnić zbrodnię” (s. 398), a przecież dziecko jest sprawą ludzkości. Xenia, teściowa bohaterki, także uważa, że synowa powinna urodzić dziecko. Gina ma żal do Miry za ujawnienie jej tajemnicy. (Nie wie, że przyjaciółka jest zakochana w jej mężu.) Początkowo protestuje przeciwko odbywającemu się nad nią sądowi familijnemu: „Jesteście bez serca dla mnie! Ja też chcę żyć!” (s. 401), ale szybko rezygnuje. Kajetan także poddaje się wyrokowi i chce zrezygnować z podróży, przed czym ostatecznie powstrzymuje go żona.

Obydwa światy łączy położenie mrowiska. Znajduje się ono w przydomowym ogrodzie Giny i Kajetana (mężczyzna zajmował się badaniem mrówek). W czasie rozmowy przyjaciółek Mira obserwuje lot godowy owadów.

\section{3 / TRANSGRESJE}

Przestrzeń dla wieloznaczności, wzajemnie się uzupełniających - pomimo (pozornych) sprzeczności - interpretacji daje zaskakująca (?) przemiana ludzkiej i nie-ludzkiej bohaterki. ${ }^{3}$

Problemy, z którymi mierzą się ludzie i mrówki, są w istocie takie same: dotyczą relacji pomiędzy jednostką - jej obowiązkami i prawami, także reprodukcyjnymi - a społeczeństwem. Analogia wydaje się jasna, zwłaszcza że Pawlikowska-Jasnorzewska utożsamiła bohaterów owadzich z ludzkimi. Wymieniając w akcie drugim osoby, w nawiasach podała ich mrówcze odpowiedniki. Podobnie wybór jednego z najbardziej społecznych gatunków w świecie zwierząt jest jak najbardziej uzasadniony. Mrówki często byly przedmiotem zainteresowania bajkopisarzy czy to starożytnych (Ezop), czy nowożytnych (Jean de La Fontaine) (por. Maeterlinck 2018: 48).

Zdecydowanie trudniej natomiast zinterpretować sam konflikt jednostka - społeczeństwo, ${ }^{4}$ na który nakłada się antagonizm pomiędzy istotami skrzydlatymi (ludzcy i mrówczy kochankowie, młodzi i piękni) a istotami „pełzającymi” - aseksualnymi robotnicami czy matronami. Ta antynomia ma silne aksjologiczne konotacje - dzieli bowiem ludzkich i nie-ludzkich protagonistów na lepszych i gorszych, na wyjątkowe indywidualności wzbijające się ponad przeciętność, piękne, utalentowane i przeznaczone do celów wyższych ${ }^{6}$ oraz na tłum

$3 \quad$ Zdaniem Marii Józefackiej przemiana Giny jest motywowana zewnętrznie, podczas gdy przemiana Illi - wewnętrznie, pod wpływem zagrożenia życia własnego, a także gatunku. Ponadto to, o co walczyła ta skrzydlata księżniczka - miłosno-seksualna relacja, symbolizowany przez skrzydła piękny wygląd zostało unicestwione: Sydis zginął, a skrzydła obcięto. Nie ma już o co walczyć, przedmiot buntu zniknął (Józefacka 1965: 88-89). Grzybowska z kolei uważa, że przemiana żeńskich bohaterek jest w obydwu przypadkach motywowana wewnętrznie, a ich ostateczne wybory pozostają dobrowolne (1936: 6).

4 Grzybowska pisze nie o konflikcie, ale o ewolucji „[...] w kierunku podporządkowania się jednostki społeczeństwu" (1936: 6).

5 Takiego określenia używa Józefacka (1965: 89).

6 Wszyscy badacze skrupulatnie odnotowują motywy skrzydeł i lotu oraz analizują ich symbolikę. Zob. Józefacka 1956: 89; Rawiński 1999: 211; Węgrzyn 2017: 164. Topos skrzydeł ma zresztą bardzo bogatą reprezentację w historii literatury i kultury. Jest obecny w greckiej mitologii (Dedal i Ikar) oraz w twórczości 
szarych istot, podobnych do siebie, skazanych na „mrówczą” pracę, monotonną, codzienną, nużącą produkcję i reprodukcję.

Wydaje się, iż w świecie ludzkim i nie-ludzkim zwycięstwo jednostki jest pozorne i nietrwałe. W istocie służy ono społeczeństwu i/lub państwu, a same jednostki (Illi/Gina) ostatecznie przyjmują za nadrzędną rację interes grupy. Pozostają w tym jednak osamotnione - Illi przeżywa jako jedyna zapłodniona księżniczka, zaś Gina odrzuca pomoc męża, a nawet matki i teściowej. Być może chcą służyć społeczeństwu na własnych zasadach, a nie jedynie podporządkować się utartym od wieków regułom. Wreszcie, ten mocno zarysowany konflikt: jednostka społeczeństwo nasuwa jeszcze jedno pytanie: czy szczęście jednostki, jej spełnienie, nie jest ważne dla dobra grupy? Psychologia dostarcza twierdzącej odpowiedzi na to pytanie.

Wyka w recenzji dramatu, a dokładnie jego pierwszej wersji scenicznej, dowodzi, że nie można mówić o równorzędności konfliktu w świecie ludzi i w świecie mrówek:

Sytuacja aktu drugiego jest tylko pewna sytuacja, pewnym przypadkowym zbiegiem zdarzeń, powodujacym konflikt, ale nie jest bynajmniej jakimś powszechnym założeniem, które zawsze wywoływałoby niemożność pogodzenia tzw. szczęścia i tzw. obowiązku. Wśród ludzi nie stwierdzamy tragicznego musu, jaki władat mrówkami; [...] (Wyka 1936: 3). ${ }^{7}$

Recenzent zwraca uwagę na biologiczny determinizm rządzący owadami i na społeczno-psychologiczne uwarunkowania, które organizują życie ludzi obok ich zwierzęcej biologii.

Podjęta w dramacie problematyka reprodukcji i rodzicielstwa wymagała wyraźnie nakreślonych żeńskich protagonistek, takich jak Illi czy Gina (warto tutaj podkreślić znaczące imię ludzkiej bohaterki - gr. gyne oznacza kobietę, ale i żonę, por. Sinko 1936: 6). Ich antagonistami bynajmniej nie są męscy bohaterowie: Sydis czy Kajetan - bierni, wycofani, niezdecydowani, wyposażeni raczej w cechy stereotypowo żeńskie, a nie męskie. Przeciwniczkami młodych kochanek są matrony - aseksualne robotnice (Xax i Xaura) i starsze kobiety - Xawera, matka Giny, i Xenia, teściowa bohaterki. Podtrzymują one zarówno matriarchalne (mrówki), jak i patriarchalne (ludzie) status quo. ${ }^{8}$ Rawiński w artykule poświęconym dramatom Pawlikowskiej-Jasnorzewskiej pisze: „Postać matrony usytuowana jest na poczesnym miejscu w wielu sztukach, w charakterze przeciwnika miłości" (1999: 205). To właśnie one kwestionują prawo młodej kobiety do przerwania ciąży, miłości i erotycznej przyjemności wolnej od reprodukcyjnej konsekwencji, mówią o obowiązkach wobec rodziny i ludzkości oraz nadzorują kochanków, przede wszystkim kobiety.

Wyka, a potem także Józefacka, wskazując różnice pomiędzy światem mrówek, którym rządzi wyłącznie biologiczny przymus, a światem ludzi, który nie zawsze zdeterminowany jest przez biologię, nie uwzględniają jednak biowładzy sprawowanej właśnie przez ludzkie matrony jako reprezentantki (i strażniczki) patriarchalnej kultury - równie silnej jak biologiczny determinizm pomimo innych kontrolujących go mechanizmów.

Akt seksualny służy więc tutaj nie wyłącznie rozmnażaniu, ale także - a może przede wszystkim - fizycznej przyjemności i umacnianiu relacji pomiędzy kochankami. Trudno go lokować

literackiej m.in. Horacego, Jana Kochanowskiego, Adama Mickiewicza, Johanna W. Goethego.

7 Odpowiadałoby to różnicy w motywacji przemiany bohaterek, o której pisze Józefacka.

8 Matriarchat zatem nie wyklucza opresji innych kobiet, choć w świeci mrówek rozumianych jako część świata zwierząt, a nie jako bohaterki dramatu, trudno chyba mówić o opresji. 
w opozycji do miłości, jest raczej jej dopełnieniem. ${ }^{9}$ Zatem to, co biologicznie (fizjologia seksu), staje się źródłem szczęścia, psychicznego dobrostanu jednostki i pełni funkcję więziotwórczą. Z tego właśnie powodu można byłoby zakwestionować tezę o radykalnie biologistycznym wymiarze Mrówek Pawlikowskiej-Jasnorzewskiej, którą postawiła Józefacka (1965: 88), ${ }^{10}$ a wcześniej Grzybowska (1936: 6). Istotą prawa do życia, o którym mówi Illi czy Gina, a które można rozumieć jako bios, ${ }^{11}$ jest w gruncie rzeczy to, co dotyczy zoe (akt seksualny). Trzeba jednak pamiętać, że chodzi o miłość fizyczną poza reprodukcją, choć tylko w przypadku Giny, ponieważ Illi nie neguje macierzyństwa. Poza tym nie można zapominać o akcie seksualnym jako o małej śmierci, w przypadku owadów tę śmierć zapowiadającą. ${ }^{12}$ Jednakże z drugiej strony to właśnie dzieci pozostają najważniejsze, zarówno dla mrówek (Xaury): „Dzieci to nasze święte larwy, duma mrowiska i treść" (s. 343), jak i dla ludzi (Xawery), dla których stają się sprawą ludzkości i przyszłości, a zatem życia (gatunkowego). Miłość i zmysły zaś są jedynie kłamstwem dla dobra gatunku (s. 424). Czy zatem Pawlikowska-Jasnorzewska, apologetka miłości, daje tutaj jej krytykę? Niekoniecznie - taki pogląd wypowiada bowiem Xax, jedna z mrówczych matron, a nie młoda samica/kobieta, z którą dramatopisarce zapewne łatwiej byłoby się utożsamić. ${ }^{13}$ Sinko zwrócił tutaj uwagę na wpływ Schopenhauerowskiej teorii o „[...] geniuszu gatunku, który dla swego utrzymania wyposaża popęd generacyjny we wszystkie czary i powaby miłości niby indywidualnej, by rozkoszą zwabić zaślepione jednostki do wydania potomstwa" (Sinko 1936: 6). ${ }^{14}$

Jeśli zatem organizacja społeczna ludzkiego i nie-ludzkiego mrowiska zostaje podporządkowana larwom i dzieciom, to $\mathrm{w}$ istocie reprodukcja staje się formą najważniejszej produkcji - o wiele ważniejszej niż mrówcza praca owadów (anonimowe robotnice) i ludzi (Kajetan). Czy dramat Pawlikowskiej-Jasnorzewskiej można więc odczytać jako pochwałę przednowoczesności, w której dominowała feudalna struktura społeczeństwa, manufaktury, a liczne potomstwo było najważniejszym kapitałem większości ludzi, żyjących zarówno w miastach, jak i na wsi? Nie można wykluczyć takiej interpretacji. Warto jednak przyjrzeć się kontekstom historycznym (i literackim) Mrówek - dramatu, który powstał na początku lat 30. XX wieku.

\section{4 / „CYWILIZAC]A MROWISKA”}

Jerzy Kwiatkowski w szkicu poświęconym Pawlikowskiej-Jasnorzewskiej stwierdza:

Mrówki-pisane zapewne nie bez wptywu znanej książki Maeterlincka-stanowią świadectwo oddziaływania na poetkę występujących już wówczas teorii o przeksztatcaniu się dwudzies-

9 Podobnie estetyka - atrakcyjny wygląd zewnętrzny, którego symbolem są u mrówczych samiczek skrzydła, zaś u kobiet wieczorowe suknie - jest formą pragmatyki; wygląd jest istotny dla nawiązywania i podtrzymywania związków partnerskich. Por. Aronson, Wilson, Akert 1997: 410-417.

10 „W ten sposób powtarza się teza Pawlikowskiej o zależności ludzi od natury, o łańcuchu, do którego zostaliśmy włączeni na tych samych prawach, co mrówka" (Józefacka 1965: 88).

11 Por. uwagi na temat posthumanistycznego rozumienia Arystotelesowskich kategorii zoe - bios (Gajewska 2011: 233-234).

12 Weselny lot przeżywa jedynie kilka samic. Zob. Maeterlinck 2018: 67.

13 Zob. konteksty biograficzne w książkach Elżbiety Hurnikowej (1999) i Anny Nasiłowskiej (2010). Niemniej świadczyłoby to o pewnym dystansie dramatopisarki wobec miłości. Por. Józefacka 1965: 89.

14 To właśnie figurę matrony Rawiński (1999: 205) wiąże z modernistyczną wizją miłości sprowadzoną, za sprawą Schopenhauera, do reprodukcji. 
towiecznej cywilizacji w „cywilizację mrowiska”. Tu znów w polu widzenia pojawia się Huxley (1979: 460).

O ile inspiracje filozoficzno-przyrodniczymi esejami Maurice’a Maeterlincka (Życie mrówek, 1930) są łatwo zauważalne (sygnalizowałam je wyżej), podobnie jak wpływ komedii autorstwa Karola i Józefa Čapków z 1922 roku pt. Z życia owadów (o czym wspomniał Sinko, a także Rawiński ${ }^{15}$ ), o tyle odwołanie do Huxleya wymaga szerszej refleksji. Przedstawiona w Nowym wspaniałym świecie (1931) automatyzacja procesu reprodukcji zasadniczo nie porusza problemu wyższości płci żeńskiej nad męską. O zbędności czy ograniczonej użyteczności tej ostatniej płci można byłoby wnioskować na podstawie ról pełnionych przez nie-ludzkie samice (królowa matka) i samców (truteń) w państwie mrówek przedstawionym w analizowanym dramacie. U Huxleya rozmnażanie wymaga udziału tylko niewielkiego odsetka ludzi niepozbawionych możliwości cielesnej reprodukcji będącej konsekwencją aktu seksualnego i zapewniającej genetyczną różnorodność. W tej dystopii rozmnażanie na skalę przemysłową jest pozacielesne - rozpoczynając od sztucznego zapłodnienia i klonowania (metoda Bokanowskiego), poprzez butlację embrionów - umieszczanie w sztucznej macicy, która zapewnia sztuczny krwiobieg, płuca i nerki aż do narodzenia, czyli wybutlacji. Wychowywanie dzieci, oparte na formach biologicznego i społeczno-psychologicznego warunkowaniu pozytywnego i negatywnego (wzmacnianie pożądanych cech i zachowań, wygaszanie niepożądanych), „produkuje” ludzi pozbawionych uczuć wyższych (abstrakcyjnych, takich jak miłość czy społecznych, takich jak patriotyzm), szczęśliwych, że mogą być robota(nika)mi: „Wszelkie warunkowanie zmierza do jednej rzeczy: do sprawienia, by ludzie polubili swe nieuniknione przeznaczenie społeczne" (Huxley 2002: 18).

Automatyzacja procesu reprodukcji daje więc ludzi-automaty, ludzi-roboty, zaś relacja między reprodukcją a produkcją ma jeszcze inny, powiedziałabym, ponowoczesny charakter: produkcja jest warunkiem reprodukcji.

W podobny sposób można odczytać Mrówki: rozmnażanie się, pomimo że cielesne, jest w biologicznym sensie zautomatyzowane. Wystarczy przyjrzeć się organizacji lotu godowego skrzydlatych owadów. Rezultatem takiej reprodukcji są kolejne pokolenia mrówczych robotnic-robotów. W świecie ludzkich zwierząt te procesy nie są tak wyraźnie przedstawione, ale poprzez utożsamienie ich z protagonistami mrówczymi nie można mieć wątpliwości co do analogii. W tej perspektywie dramat Pawlikowskiej-Jasnorzewskiej jest egzemplifikacją popularnych w dwudziestoleciu międzywojennych wizji (po)nowoczesnego świata przyszłości - wizji niejednokrotnie utopijnych i/lub dystopijnych, czy to w zakresie organizacji politycznej czy społecznej (można tutaj wskazać faszyzm czy bolszewizm).

Jednocześnie Mrówki odzwierciedlają kryzys programowych haseł nowoczesności głoszonych na początku lat 20. XX wieku, takich jak hasło Awangardy Krakowskiej: miasto - masa maszyna. Można go z pewnością wiązać z zapaścią ekonomiczną przełomu lat 20. i 30. minionego stulecia. Wielki Kryzys w świecie Zachodu, w którym gospodarki opierały się w dużej mierze na powszechnej pracy ludzkich mas w uprzemysłowionych ośrodkach miejskich, a której rezultatem były masowo wytwarzane dobra konsumpcyjne, obnażył - po raz kolejny - (prawdziwe) oblicze kapitalizmu i iluzję egzystencjalnego bezpieczeństwa robotników i robotnic. Gospodarcza zapaść przyczyniła się z kolei do wzrostu tendencji totalitarnych w Europie i do nasilenia 
autorytaryzmu polskiego rządu. Konsekwencją totalitaryzmu było gwałcenie praw jednostki, ogólnie - praw człowieka. Dla autorytarnych władców dzieci są przyszłością ludzkości, która nie tyle rozwija się cywilizacyjnie i dlatego potrzebuje pracujących mas (bo w okresie kryzysów gospodarczych ludzkie masy zasilające rzesze bezrobotnych stają się bezużyteczne i zbędne), ile prowadzi wojny i potrzebuje „mięsa armatniego”. Takie mrówcze państwa prowadzące wojny przedstawili właśnie bracia Čapkowie.

Analizę państwa mrówek z perspektywy sytemu totalitarnego zapowiadającego faszyzm proponowali już recenzenci omawianego dramatu - Sinko i Grzybowska. Józefacka z kolei wskazała satyryczne cechy Mrówek, korzystające z ironii czy groteski. W rozumieniu badaczki groteska obecna m.in. w wypowiedziach Xuary (oraz Xanto) w pierwszych scenach pierwszego aktu służy skompromitowaniu państwa mrówek - pokazaniu bezprawia, które ma rzekomo Wzmacniać społeczeństwo (Józefacka 1965: 70).

W tym sensie dramat Pawlikowskiej-Jasnorzewskiej byłby krytycznym - myślę - głosem $\mathrm{w}$ dyskusji o przemianach dwudziestowiecznego społeczeństwa w „cywilizację mrowiska”. Mrowiska, które już wkrótce - jak w finałowej scenie trzeciego aktu - ulegnie zagładzie. Trzy lata po premierze dramatu wybuchła II wojna światowa. Mrówki okazały się sztuką nie tylko krytyczną, ale i profetyczną.

\section{5 / OD KONSTUKTYWIZMU DO POSTHUMANIZMU}

Inga Iwasiów nazywa Mrówki „[...] jedyną sztuką Pawlikowskiej-Jasnorzewskiej nadającą macierzyństwu rangę posłannictwa: zbuntowana miłośnica Illi i bezgranicznie zakochana w mężu Gina stają na gruzach mrowiska-małżeństwa nosząc w sobie odwagę na trwanie gatunku, dziecko" (1996: 145).

Wybór mrówek jako alegorii ludzi byłby nieprzypadkowy nie tylko ze względu na ich literacką popularność - myrmekolodzy, badacze różnych mrówczych społeczności zwracają uwagę na to, jak bardzo mrówki dbają o swoje larwy (zob. Maeterlinck 2018: 45). W dramacie Pawlikowskiej-Jasnorzewskiej widoczne jest to już w pierwszych scenach, kiedy Xaura mówi: „Dzieci to nasze święte larwy, duma mrowiska i treść" (s. 343). W tej perspektywie, inaczej niż dowodził Kazimierz Wyka, można obronić tezę o podobieństwie problemów ludzi i mrówek. Triumf reprodukcyjnego wymiaru aktu seksualnego byłby z jednej strony konstatacją dominacji praw społecznych nad prawami jednostki, zwycięstwem nie-ludzkiej zoe nad bios. Konstatacją chyba jednakgorzkąi smutną - Pawlikowska-Jasnorzewska dystansuje sięw Mrówkach do macierzyństwa rozumianego jako instytucja i forma opresji. Ważne tutaj okazują się propozycje Józefackiej, która czyta nie tylko ten dramat autorki Ciszy leśnej jako satyrę korzystającą z ironii i groteski.

Gdyby jednak spojrzeć na finał Mrówek z perspektywy współczesnej posthumanistyki, należałoby dowartościować żeńskie zdolności reprodukcyjne jako synonim życia gatunkowego, ciągłego, nieskończonego w odróżnieniu od skończonego życia jednostkowego podmiotu. Rosi Braidotti uznaje „[...] ten postantropocentryczny zwrot za konieczny punkt wyjścia dla etyki trwałości dążącej do skupienia się na posthumanistycznej pozytywności zoe" (Braidotti 2014: 238-239). Ten posthumanistyczny dyskurs nawiązuje $\mathrm{w}$ istocie do dyskusji podejmowanych przez anglosaskie feministki kulturowe i/lub radykalne co najmniej od lat 60 . XX wieku. Jego przedstawicielki, np. Adrienne Rich w książce Zrodzone z kobiety (1979), domagały się uznania 
biologicznych zdolności reprodukcyjnych kobiety, nie kwestionując zasadniczo praw reprodukcyjnych. Inne z kolei, np. Shulamith Firestone (The Dialectic of Sex, 1970), widziały w naturalnej możliwości rodzenia dzieci źródło opresji. ${ }^{16}$ Różne odczytania dramatu świetnie antycypują i egzemplifikują tę dyskusję. Była ona odmienna od debaty na temat świadomego macierzyństwa, która toczyła się na przełomie lat 20. i 30. XX wieku w Polsce na łamach „Wiadomości Literackich" i w którą angażowała się także autorka Mrówek. Ta dyskusja bowiem bardziej koncentrowała się na antykoncepcji i prawie do aborcji, a zatem na możliwościach ograniczenia biologicznej zdolności reprodukcyjnej kobiet. Jej echa widoczne są w analizowanego dramacie, w akcie drugim rozgrywającym się wśród ludzi.

Obrazy ludzkiego i nie-ludzkiego mrowiska wpisują się zatem we współczesny posthumanizm, a także w feministyczny dyskurs drugiej polowy XX wieku dotyczący zdolności reprodukcyjnych kobiet - Mrówki Pawlikowskiej-Jasnorzewskiej antycypują zatem ponowoczesny posthumanizm, tak jak zapowiadają feminizm drugiej fali. Z drugiej strony, co dość zaskakujące, można byłoby obronić ten dramat jako pochwałę przednowoczesności. Bo w nowoczesność Mrówki wpisują się w sposób najbardziej, pomimo symbolizacji, literalny - szeroko dyskutowany przez krytyków i badaczy. Wynika to zapewne z czasu powstania sztuki. Ten historyczny kontekst nie stracił ani na uniwersalności, ani na aktualności. Więcej - wydaje się obecnie najbardziej wyrazisty. Na początku XXI wieku, podobnie jak w latach 30. minionego stulecia, możemy obserwować w zachodnim świecie wzrost totalitaryzmu i autorytaryzmu powiązany z kryzysami ekonomicznymi czy pandemią. W Polsce dodatkowo z kolejnymi próbami wprowadzenia całkowitego zakazu prawa do aborcji. Obserwowana obecnie popularność tendencji totalitarnych wiąże się także z nowymi problemami, specyficznymi jednak dla ponowoczesności - rewolucją cyfrową, terroryzmem, kryzysem klimatycznym i uchodźczym.

Polisemantyczność utworu, owocująca wielością interpretacyjnych możliwości i perspektyw badawczych, świadczy o niewątpliwej wartości artystycznej analizowanego dramatu i stoi za jego sukcesem scenicznym. ${ }^{17}$ Sinko dowartościował talent autorki Krystylizacji, stawiając ją w jednym rzędzie z Nałkowską: „Mrówki pasują p. Jasnorzewską na współregentkę pani Nałkowskiej we współczesnej literaturze. Czym tamta w powieści (choć i w dramacie okazała duży talent), tym ta świetna liryczka dziś w teatrze" (Sinko 1936: 6).

O wartości artystycznej Mrówek stanowi wreszcie aktualność dramatu.

\section{IN THE HUMAN AND THE NON-HUMAN WORLD. (POST)MODERN SOCIETY AND THE FEMALE SEX IN MRÓWKI (ANTS) BY MARIA PAWLIKOWSKA- JASNORZEWSKA}

SUMMARY Created before 1932, Maria Pawlikowska-Jasnorzewska's drama entitled Ants (Mrówki) may be called - following Stanisław Treugutt - a "animal-human parallel". The play juxtaposes two worlds: a human one (family) and

16 Feministyczną dyskusję na temat znaczenia zdolności reprodukcyjnych kobiet zreferowała Rosemarie Putnam Tong (2002: 96-116).

$17 \quad$ Na ten ostatni sukces niewątpliwy wpływ miały także aktorstwo, reżyseria i scenografia. Zob. Sinko 1936: 6; Grzybowska 1936: 6. 
a non-human one - the community of ants. Careful analysis of the oppositions constituting the drama: ants - humans, society - individual, female - male, sexual act - love, reproduction - production, zoe - bios, etc. leads to the conclusion that they are not unambiguous, and do not constitute opposing poles, but rather interpenetrate. Indeed, these quasi-oppositions allow a broadening of interpretative horizons. On the one hand, they enable us to treat the play as an exemplification of visions of a (post)modern world of the future, popular in the inter-war period - visions that were frequently utopian and/or dystopian, whether in terms of political or social organisation. On the other hand, Ants anticipate contemporary posthumanism, as well as the feminist discourse of the second half of the $20^{\text {th }}$ century, concerning women's reproductive rights. One may look at the play, and especially its conclusion - as appreciating female reproductive potential, which is synonymous with the life of a species, constant and never-ending, in contrast with the finite life of an individual subject. Polysemanticity, the multiplicity of possible interpretations and research perspectives testify to the undeniable artistic value of the play.

Translated by Stawomir Konkol

\section{LITERATURA}

I Aronson E. - Wilson T. D. - Akert R. M., 1997, Psychologia społeczna. Serce i umyst, przeł. A. Bezwińska i in., Poznań.

I Braidotti R., 2014, Po człowieku, przeł. J. Bednarek, A. Kowalczyk, Warszawa.

I Čapek K. - Čapek J., 1982, Ze života hmyzu. Ze společnétvorby, Praha.

I Dąbrowska M., 2018, Próba pasienia kotów czyli intelektualny krajobraz animal studies, „Wielogtos", 1, s. 15-31.

I Gajewska G., 2011, Człowiek/zwierzę/roślina, „Studia Europaea Gnesnensia”, 4, s. 225-246.

I Grzybowska K., 1936, Triumf „Mrówek” na scenie krakowskiej, „Czas”, 318, s. 6.

I Hurnikowa E., 1999, Maria Pawlikowska-Jasnorzewska. Zarys monograficzny, Katowice.

I Huxley A., 2002, Nowy wspaniały świat, przeł. B. Baran, Warszawa.

I Iwasiów I., 1996, Oblicza „Ja” - o świadomości bohaterek dramatów Marii Pawlikowskiej-Jasnorzewskiej, Stulecie Skamandrytów, red. K. Biedrzycki, Kraków, s. 137-148.

I Józefacka M., 1965, Krystalizacje dramatyczne. Komedie Marii PawlikowskiejJasnorzewskiej, „Roczniki Humanistyczne”, 1, t. 13, s. 67-97.

I Kaszowska-Wandor B., 2018, Teriantropie. Animal studies i (od)stawanie się człowiekiem, „Wielogtos”, 1, s. 33-61.

I Kwiatkowski J., 1979, Maria Pawlikowska-Jasnorzewska, Obraz literatury polskiej XIX i XX wieku. Seria 6: Literatura polska w okresie międzywojennym, t. 2, red. J. Kądziela i in., Kraków, s. 452-470.

I Maeterlinck M., 2018, Życie mrówek, przeł. A. i M. Czartkowscy, Kraków.

I Nasiłowska A., 2010, Maria Pawlikowska-Jasnorzewska, czyli Lika Kossak. Biografia poetki, Torun.

I Pawlikowska-Jasnorzewska M., 1986, Mrówki. Sztuka w trzech aktach, Dramaty, t. 1, oprac. A. Bolecka, Warszawa, s. 337-428. 
I Putnam Tong R., 2002, Myśl feministyczna. Wprowadzenie, przeł. J. Mikos, B. Umińska, Warszawa.

I Rawiński M., 1999, „Przez sprawę miłości widziana sprawa kobiety”. Feministyczny teatr Pawlikowskiej-Jasnorzewskiej, „Annales Universitatis Mariae Curie-Skłodowska Lublin - Polonia. Secctio FF", vol. XVII, s. 193-215.

I Sinko T., 1936, Gatunek i jednostka. „Mrówki”. Sztuka w trzech aktach Marii Jasnorzewskiej, „Czas”, 313, s. 6.

I Szałagan A., 1999, Pawlikowska-Jasnorzewska Maria, Wspótcześni polscy pisarze i badacze literatury. Stownik biobibliograficzny, t. 6, red. J. Czachowska, A. Szałagan, Warszawa, s. 286-292.

I Treugutt S., 1986, Zamawianie pięknej choroby, M. Pawlikowska-Jasnorzewska, Dramaty, t. 1, oprac. A. Bolecka, Warszawa, s. 5-26.

I Węgrzyn K., 2017, Teatralne prymicje czarownicy z Krakowa. Rozkwitający feminizm w wybranych dramatach Pawlikowskiej-Jasnorzewskiej, „Zagadnienia Rodzajów Literackich”, 2, t. LX, s. 161-167.

I Wyka K., 1936, „Mrówki” Marii Jasnorzewskiej, „Gazeta Polska”, 320, s. 3-4. 